\title{
Novel species of Cercospora and Pseudocercospora (Capnodiales, Mycosphaerellaceae) from Australia
}

\section{Roger Graham SHIVAS*, Thomas Stephen MARNEY, Yu Pei TAN, Alistair Ross MCTAGGART}

Plant Pathology Herbarium, Department of Agriculture, Fisheries and Forestry, Dutton Park, Queensland 4102, Australia

\section{A R T I C L E I N F O}

Article history:

Received 30 June 2014

Received in revised form

5 September 2014

Accepted 21 September 2014

Available online 5 October 2014

Corresponding Editor:

Kevin Hyde

Keywords:

Cercosporoid

Mycology

Phylogeny

Systematics

Taxonomy

\begin{abstract}
A B S T R A C T
Novel species of Cercospora and Pseudocercospora are described from Australian native plant species. These taxa are Cercospora ischaemi sp. nov. on Ischaemum australe (Poaceae); Pseudocercospora airliensis sp. nov. on Polyalthia nitidissima (Annonaceae); Pseudocercospora proiphydis sp. nov. on Proiphys amboinensis (Amaryllidaceae); and Pseudocercospora jagerae sp. nov. on Jagera pseudorhus var. pseudorhus (Sapindaceae). These species were characterised by morphology and an analysis of partial nucleotide sequence data for the three gene loci, ITS, LSU and EF-1 $1 \alpha$. Recent divergence of closely related Australian species of Pseudocercospora on native plants is proposed.
\end{abstract}

Crown Copyright @ 2014 Published by Elsevier Ltd on behalf of The British Mycological Society. All rights reserved.

\section{Introduction}

Cercospora Fresen. and Pseudocercospora Speg. are large genera of mostly plant pathogenic fungi, containing over 3500 and 1600 species names respectively (www.mycobank.org). The delimitation of species within Cercospora and Pseudocercospora, as well as the circumscription of the genera, has changed since their establishment by Fresenius (1863) and Spegazzini (1910), respectively. These changes have resulted from critical evaluation of the taxonomic importance of morphology (Chupp 1954; Crous \& Braun 2003), host specificity (Deighton 1976, 1979) and molecular phylogeny (Crous et al. 2000). Together these characteristics provide the basis for a stable taxonomy that resolves both generic and species limits for Cercospora (Groenewald et al. 2013) and Pseudocercospora (Crous et al. 2013).

The Australian cercosporoid fungi, including Cercospora and Pseudocercospora, have never been comprehensively revised. Since the application of phylogenetic analysis of DNA sequence data to fungal systematics in the last decade, several new Australian species of Cercospora (Crous et al. 2013) and Pseudocercospora (Shivas et al. 2009a, 2009b; 2010; Crous et al. 2010a, 2010b 2011; McTaggart et al. 2010) have been discovered and named. An examination of recently collected specimens of leaf spots on some native plants from eastern Queensland, revealed further novel species of Cercospora and Pseudocercospora.

\footnotetext{
* Corresponding author. Tel.: +61 732554378.

E-mail addresses: roger.shivas@daff.qld.gov.au (R. G. Shivas), thomas.marney@daff.qld.gov.au (T. S. Marney), yupei.tan@daff.qld. gov.au (Y. P. Tan), alistair.mctaggart@daff.qld.gov.au (A. R. McTaggart). 


\section{Materials and methods}

\section{Isolates}

Conidia and conidiophores were removed with the tip of a scalpel from leaf spots on freshly pressed herbarium specimens of four native Australian plants, viz., Ischaemum australe, Jagera pseudorhus var. pseudorhus, Polyalthia nitidissima, and Proiphys amboinensis. The conidia were suspended in a droplet of water and spread on plates of potato dextrose agar (PDA) amended with $100 \mu \mathrm{g} \mathrm{ml}^{-1}$ streptomycin sulphate, and incubated at room temperature $\left(23-25^{\circ} \mathrm{C}\right.$ ) under ambient light. From these plates single conidial colonies were established on PDA after 1-3 d.

\section{DNA extraction, amplification and phylogeny}

Mycelia were scraped off PDA cultures and macerated with $0.5 \mathrm{~mm}$ glass beads (Daintree Scientific) in a Tissue Lyser (QIAGEN). Genomic DNA was then extracted with the Gentra Puregene DNA Extraction kit (QIAGEN (Venlo, Limburg, The Netherlands)) according to the manufacturer's instructions.

The internal transcribed spacer (ITS) region of nuclear ribosomal DNA (rDNA) was amplified with the primers ITS1F (Gardes \& Bruns 1993) and ITS4 (White et al. 1990). The large subunit region of rDNA was amplified with LROR and LR6 (Vilgalys \& Hester 1990). Part of the translation elongation factor 1- $\alpha(E F-1 \alpha)$ gene was amplified with the primers EF1-728 F (Carbone \& Kohn 1999) and EF2 (O'Donnell et al. 1998). All PCRs were performed with high fidelity Phusion enzyme (New England Biolabs) according to the manufacturer's instructions. The PCRs were performed with the following annealing temperatures: ITS and LSU at $62^{\circ} \mathrm{C}$, and EF- $1 \alpha$ at $60^{\circ} \mathrm{C}$. PCR products were sent to Macrogen Korea for purification and direct sequencing.

The systematic placement of the new taxa described herein is based on the phylogeny of the LSU region recovered by Crous et al. (2013). The 14 clades recovered by Crous et al. (2013) were represented by 49 species. Type species were used when available. The four newly described cercosporoid fungi and three previously described species from Australia were also included. Saccharomyces cerevisiae was selected as an outgroup taxon as used by Crous et al. (2013). The LSU sequences were aligned in MAFFT (Katoh et al. 2009) (available: http://www.ebi.ac.uk/Tools/msa/mafft/), and analysed with two phylogenetic criteria, maximum likelihood (ML) and Bayesian inference. Maximum likelihood was implemented as a search criterion in RAxML (Stamatakis 2006). GTRGAMMA was specified as the model of evolution for nucleotide sequence data. The RAxML analyses were run with a rapid Bootstrap analysis (command - $f$ a) using a random starting tree and $1000 \mathrm{ML}$ bootstrap replicates. A Markov Chain Monte Carlo (MCMC) search in a Bayesian analysis was conducted with MrBayes (Ronquist \& Huelsenbeck 2003). Four runs, each consisting of four chains, were implemented for 5 million generations. The cold chain was heated at a temperature of 0.25 . Substitution model parameters were sampled every 500 generations and trees were saved every 500 generations. Convergence of the Bayesian analysis was confirmed using
AWTY (Nylander et al. 2008) (available at: ceb.csit.fsu.edu/ awty/) and used to calculate a burnin. The final topology was summarised from 4200 trees generated in four runs. The ML and Bayesian analyses were run three times to test accuracy.

\section{Taxonomy}

Morphological descriptions are based on fungal structures in plantae. Fungal structures were mounted on glass sides in clear lactic acid $(100 \% \mathrm{v} / \mathrm{v})$. At least 30 measurements $(\times 1000)$ were made if possible, with values expressed as ranges and outliers given in parentheses. Microscopic observations were made with a Leica DM 2500 compound microscope using differential interference contrast illumination and a Leica DFC 550 camera. Colony colours were determined on PDA and/or oatmeal agar (OMA) at $25^{\circ} \mathrm{C}$ in the dark after $4 \mathrm{wk}$, using the colour charts of Rayner (1970). Nomenclatural novelties and descriptions were deposited in MycoBank (www.MycoBank.org).

\section{Results}

\section{Phylogeny}

The tree topologies recovered by ML and Bayesian inference were identical (Fig 1) and represented the 14 major clades defined by Crous et al. (2013). Cercospora eremochloae (HM235406) on Eremochloa (Poaceae) and one isolate (BRIP 56010) on Ischaemum (Poaceae), were sister to several species of Cercospora, which was non-monophyletic in the study by Crous et al. (2013). The other three isolates (BRIP 58545, BRIP 58549 and BRIP 58550) belonged to a well-supported clade (90 \% bootstrap; 1.0 posterior probability) that corresponded to Pseudocercospora s. str. (Crous et al. 2013) and contained the type species, Pseudocercospora vitis.

\section{Taxonomy}

Based on the phylogenetic analysis and morphological characteristics, four novel species are described.

Cercospora ischaemi R.G. Shivas, Marney \& McTaggart, sp. nov. Fig 2.

MycoBank MB 809257.

Etymology. Named after the host plant genus, Ischaemum.

Leaf spots amphigenous, linear to narrowly ellipsoidal, bordered by parallel leaf veins, up to $1 \mathrm{~cm}$ long and $1 \mathrm{~mm}$ wide, dark reddish brown to dark brown, with a narrow yellowish diffuse halo up to $0.5 \mathrm{~mm}$ wide, scattered, of similar appearance on upper and lower leaf surfaces. Caespituli epiphyllous, inconspicuous. Mycelium internal. Stromata absent. Conidiophores erumpent through the cuticle, in loose fascicles of $2-5$, erect, subcylindrical, $10-60 \times 3-5 \mu \mathrm{m}$, sometimes geniculate, 0-1 septate, pale brown to subhyaline, thin-walled, smooth; conidiogenous cells, terminal, subcylindrical, 10-60 $\mu \mathrm{m}$, sympodial, hyaline to subhyaline, smooth, polyblastic; conidiogenous loci conspicuous, flat, circular, thickened, and darkened, 1.5-2.0 $\mu \mathrm{m}$ wide. Conidia obclavate, 


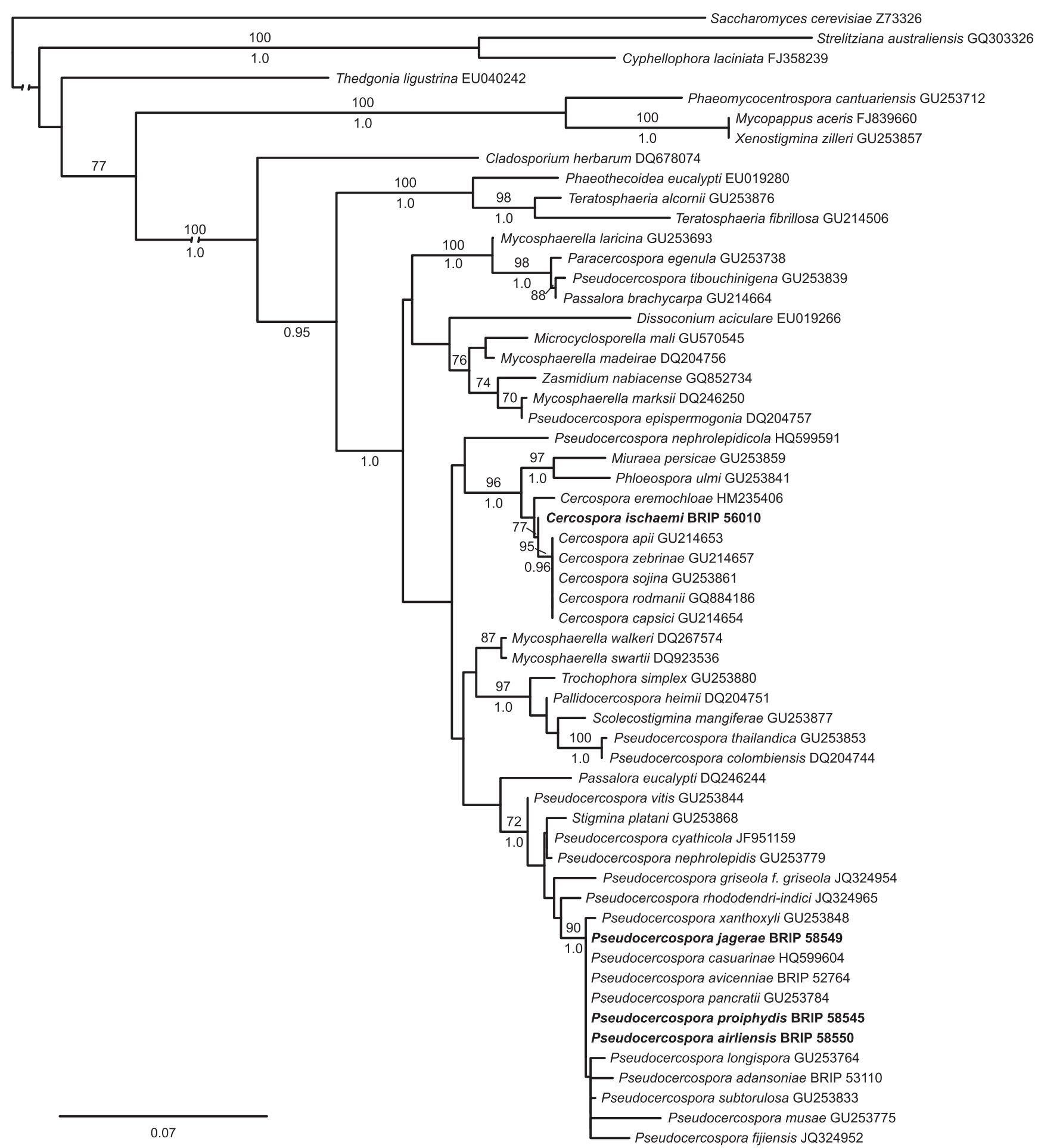

Fig 1 - Phylogram obtained from a maximum likelihood search in RAxML based on the nuclear LSU region of rDNA. Bootstrap support ( $\geq 70 \%$ ) values from 1000 replicates above nodes. Posterior probabilities ( $\geq 0.95)$ from 4200 trees in a Bayesian search are shown below nodes.

with a narrowly obconically truncate base and attenuated towards the apex, 60-120 × 4-5 $\mu \mathrm{m}, 1-3$-septate, hyaline, smooth, thin-walled; hila thickened, and darkenedrefractive, $1.5-2.0 \mu \mathrm{m}$ wide.
Culture characteristics - (in the dark, $23^{\circ} \mathrm{C}$, after $4 \mathrm{wk}$ ): Colonies on PDA agar $5 \mathrm{~cm}$ diam., flat with scarce aerial mycelium, pale mouse grey with irregular pale, and darker patches, margin irregularly crenate; reverse fuscous black, and paler 

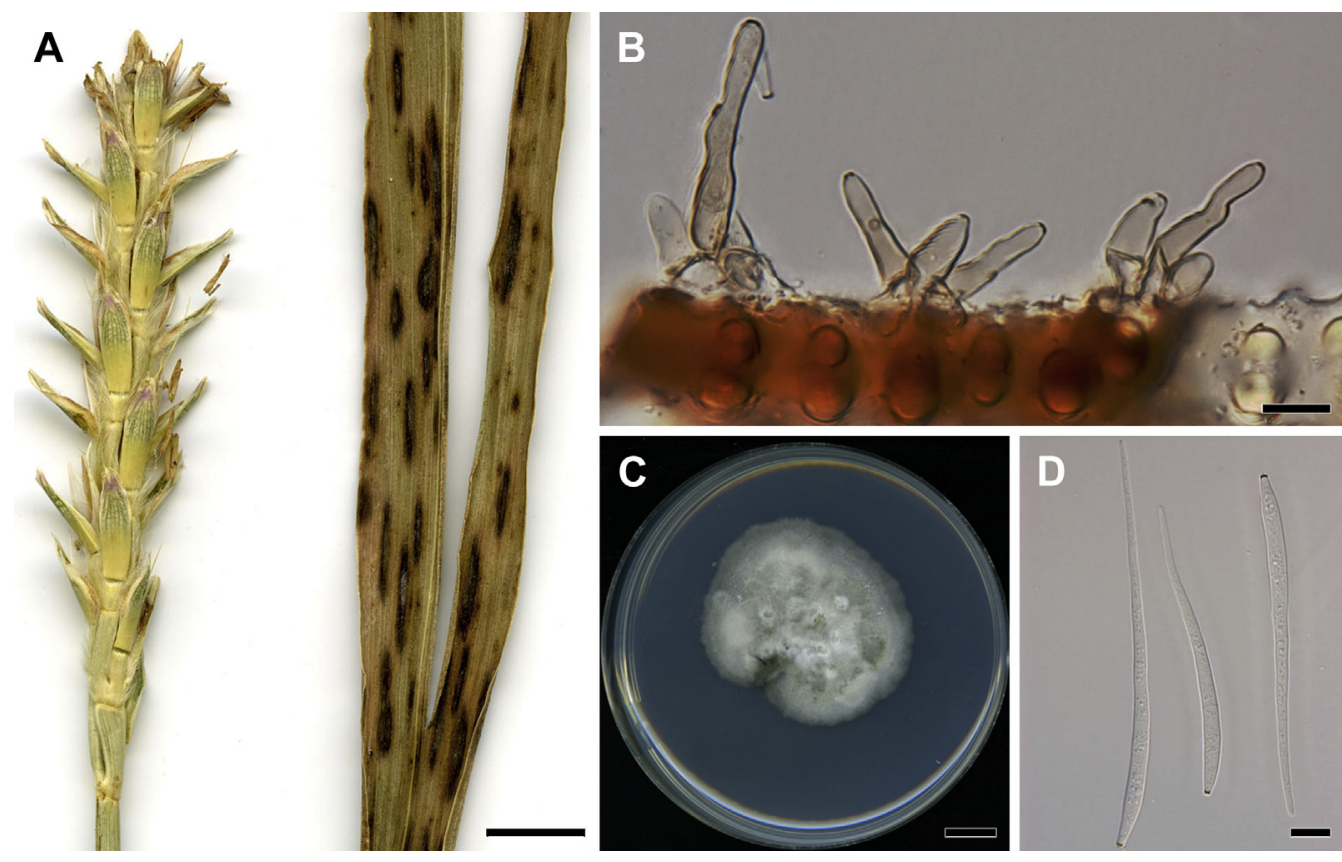

Fig 2 - Cercospora ischaemi (from holotype BRIP 56010). (A). Leaf spots on Ischaemum australe (right) and healthy inflorescence (left); (B). Conidiophores; (C). Colony on PDA after 4 weeks; (D). Conidia. Bars: (A) =1 cm; (B, D) =10 10 ; (C) =1 cm.

towards the margin. On OMA $2.5 \mathrm{~cm}$ diam., flat with scarce aerial mycelium, pale mouse grey, zonate, faintly rosy vinaceous towards the margin, reverse fuscous black; on malt extract agar $3 \mathrm{~cm}$ diam., flat, radially wrinkled, margin entire, grey olivaceous, reverse black.

Typus. Australia, Northern Territory, Victoria River Downs, S $15^{\circ} 36^{\prime} 4.7356^{\prime \prime} \mathrm{E} 131^{\circ} 12^{\prime} 48.5903^{\prime \prime}$, on leaves of Ischaemum australe (Poaceae), 20 Apr. 2012, R.G. Shivas (holotype BRIP 56010; includes ex-type culture), ITS sequence GenBank KM055428, LSU sequence GenBank KM055432.

Other specimens examined. Australia, Western Australia, unnamed swamp about $140 \mathrm{~km}$ northwest of Kununurra, S $14^{\circ}$ 41.698', E $128^{\circ} 02.344^{\prime}$, M.P. Weinert (BRIP 51367).

Notes - Cercospora ischaemi is known from two collections in northern Australia. A specimen (BRIP 4473) on Ischaemum australe from Queensland had comparable symptoms to $C$. ischaemi, but morphological examination indicated the fungus differed and warrants further study. Cercospora ischaemi, together with $C$. eremochloae, are recently described species from native Australian tropical grasses (Crous et al. 2011). Cercospora coniogrammes (JX143583) on Coniogramme (Pteridaceae) from Australia had the highest identity ( $96 \%$, 496/518 identical base pairs) to $C$. ischaemi in a BLAST search of the ITS region of rDNA.

Pseudocercospora airliensis R.G. Shivas, Marney \& Y.P. Tan, sp. nov. Fig 3.

MycoBank MB 809258.

\section{Etymology. Named after Airlie Beach.}

Leaf spots amphigenous, irregular, sometimes bordered by leaf veins, 1-4 mm diam., with pale tan to dark grey centres and irregular black borders up to $0.5 \mathrm{~mm}$ wide, often surrounded by a diffuse pale yellowish irregular halo that extends for 2-15 mm, scattered, of similar appearance on upper and lower leaf surfaces. Caespituli mostly hypophyllous, dense, dark, punctiform. Mycelium internal. Stromata erumpent from centres of leaf spots, reddish brown, up to $80 \mu \mathrm{m}$ diam. and $70 \mu \mathrm{m}$ high. Conidiophores in loose fascicles of 5-30, erect, subcylindrical, geniculate to sinuous, 20-70 $\times 3-4 \mu \mathrm{m}$, sometimes with one or more branches, 0-8-septate, pale to medium brown, smooth, thin-walled; conidiogenous cells, terminal, integrated, subcylindrical to geniculate, $10-20 \mu \mathrm{m}$, hyaline, smooth, monoblastic or sometimes polyblastic, proliferating percurrently; conidiogenous loci inconspicuous. Conidia cylindrical, straight or curved to flexuous, with a narrowly obconically truncate base and attenuated towards the apex, 25-60 × 2-4 $\mu \mathrm{m}, 2-7$-septate, subhyaline to pale brown, smooth, thin-walled; hila truncate, 1-2 $\mu \mathrm{m}$ wide, unthickened, and not darkened.

Culture characteristics - (in the dark, $23^{\circ} \mathrm{C}$, after $4 \mathrm{wk}$ ): Colonies on PDA up to $2 \mathrm{~cm}$ diam., flat with scarce aerial mycelium, cream to faintly rosy vinaceous; reverse dark brown, paler towards the margin.

Typus. Australia, Queensland, Airlie Beach, Mount Conway Range, S $20^{\circ} 20^{\prime}$ E $148^{\circ} 46^{\prime}$, on leaves of Polyalthia nitidissima (Annonaceae), 4 Apr. 2013, R.G. \& M.D.E. Shivas (holotype BRIP 58550; includes ex-type culture), ITS sequence GenBank KM055429, LSU sequence GenBank KM055433, EF-1 $\alpha$ sequence GenBank KM055436.

Notes - Polyalthia nitidissima is a tree species found in dry rainforests and along watercourses in eastern and northern Australia, extending to New Caledonia and New Guinea. One other species of Pseudocercospora, P. polyalthiae, has 

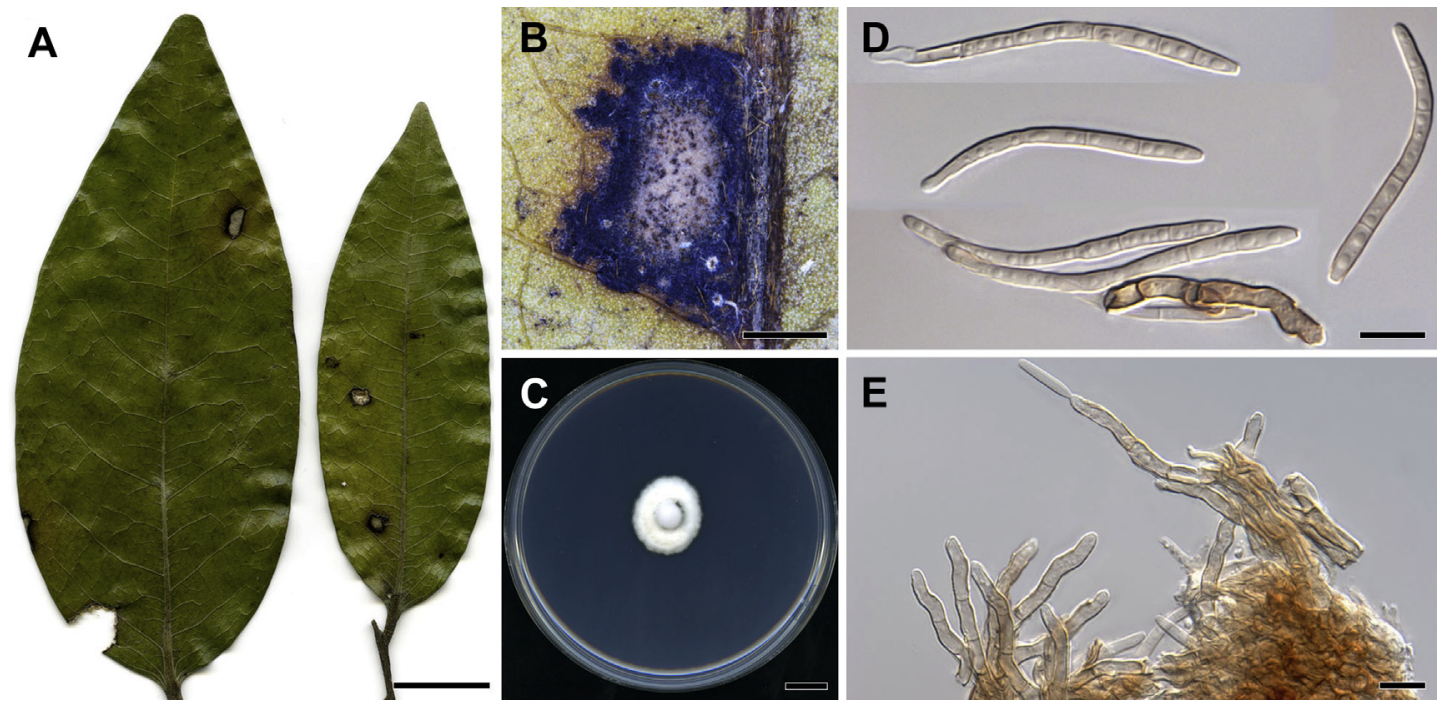

Fig 3 - Pseudocercospora airliensis (from holotype BRIP 58550). (A, B). Leaf spots on Polyalthia nitidissima; (C). Colony on PDA after 4 weeks; (D). Conidia; (E). Conidiophores. Bars: (A, C) $=1 \mathrm{~cm}$; (B) $=1 \mathrm{~mm}$; (D, E) = $10 \mu \mathrm{m}$.

been recorded on Polythia (type on Polythia suberosa, India) (Yen et al. 1982). Pseudocercospora polyalthiae lacks stromata and has simple conidiophores not in fascicles, which differ from P. airliensis. Braun \& Crous (2008) provided a key for the cercosporoid fungi on hosts in the Annonaceae. Using this key led to P. aethiopicae (type on Xylopia aethiopicae, Sierra Leone), which differs from P. airliensis by having simple, continuous or 1-2 septate conidiophores. Pseudocercospora tereticornis (GQ852770 and GQ85277) on Eucalyptus (Myrtaceae) from Australia had the highest identity (99\%, 570/577 identical base pairs) to P. airliensis in a BLAST search of the ITS region of rDNA.

Pseudocercospora proiphydis R.G. Shivas, Marney \& Y.P. Tan, sp. nov. Fig 4.

MycoBank MB 809297.

Etymology. Named after the host plant genus, Proiphys.

Leaf spots amphigenous, circular to ellipsoidal or irregular, up to $3 \mathrm{~cm}$ diam., pale brown with diffuse irregular halo that extends for up to $1 \mathrm{~cm}$, scattered, of similar appearance on both leaf surfaces. Caespituli mostly hypophyllous, abundant on leaf spots, dense, dark, punctiform. Mycelium internal. Stromata erumpent from stomata, dark brown, up to $60 \mu \mathrm{m}$ high and $50 \mu \mathrm{m}$ wide. Conidiophores in fascicles of up to 60 , arising from stromata, erect, subcylindrical, slightly tapered towards the rounded apex, straight or slightly curved to geniculate, 10-70 × 3-6 $\mu \mathrm{m}$, unbranched, 0-5-septate, subhyaline to pale brown, smooth, thin-walled; conidiogenous cells, terminal, integrated, subcylindrical, 20-60 $\mu \mathrm{m}$, hyaline, smooth, monoblastic or polyblastic, proliferating percurrently; conidiogenous loci slightly thickened, 1-2 $\mu \mathrm{m}$. Conidia cylindrical to narrowly lageniform, straight, obconically truncate at the base and rounded at the apex, 25-120 × 2-6.5 $\mu \mathrm{m}, 5-10$ septate, subhyaline to pale brown, smooth, thin-walled; hila sometimes slightly thickened, 1-2 $\mu \mathrm{m}$ wide.
Culture characteristics - (in the dark, $23^{\circ} \mathrm{C}$, after $4 \mathrm{wk}$ ): Colonies on PDA up to $1 \mathrm{~cm}$ diam., domed with scarce aerial mycelium, olivaceous grey.

Typus. Australia, Queensland, Shute Harbour, in deep shade near forest walk lookout, $20^{\circ} 16^{\prime} 44^{\prime \prime} \mathrm{S}, 148^{\circ} 47^{\prime} 42^{\prime \prime} \mathrm{W}$, on leaves of Proiphys amboinensis (Amaryllidaceae), 3 Apr. 2013, R.G. \& M.D.E. Shivas (holotype BRIP 58545; includes ex-type culture), ITS sequence GenBank KM055430, LSU sequence GenBank KM055434, EF-1 $\alpha$ sequence GenBank KM055437.

Other specimens examined. Australia, Queensland, Mt Nebo, on leaf spots on Proiphys cunninghamii, J.H. Simmonds, 15 Apr. 1972, J.H. Simmonds (BRIP 8746); Mt Nebo, on leaf spots on P. cunninghamii, R.G. Shivas, 1 Mar. 1972, J.H. Simmonds (BRIP 39565).

Notes - Proiphys amboinensis is a perennial herbaceous bulbous plant found in rainforests of subtropical eastern Australia and Southeast Asia. Pseudocercospora proiphydis is morphologically similar to P. pancratii (Braun \& Castañeda 1991), which has been reported on several genera in the Amaryllidaceae (Crous \& Braun 2003). The molecular sequence data showed that P. proiphydis and P. pancratii differ genetically in the ITS region (GU269759: $88 \%$ identical over $97 \%$ query coverage) and the EF- $1 \alpha$ region (GU384470: $82 \%$ identical over $97 \%$ query coverage). Moreover, slightly thickened conidiogenous loci are not present in P. pancratii. These results indicate that $P$. pancratii may represent a complex of closely related species. Pseudocercospora jagerae R.G. Shivas, Marney \& Y.P. Tan, sp. nov. Fig 5.

MycoBank MB 809298.

\section{Etymology. Named after the host plant genus, Jagera.}

Leaf spots amphigenous, of similar appearance on both leaf surfaces, irregular, bordered by veins, 1-4 $\mathrm{mm}$ diam., with grey centres and purplish brown borders c. $0.5 \mathrm{~mm}$ wide, 

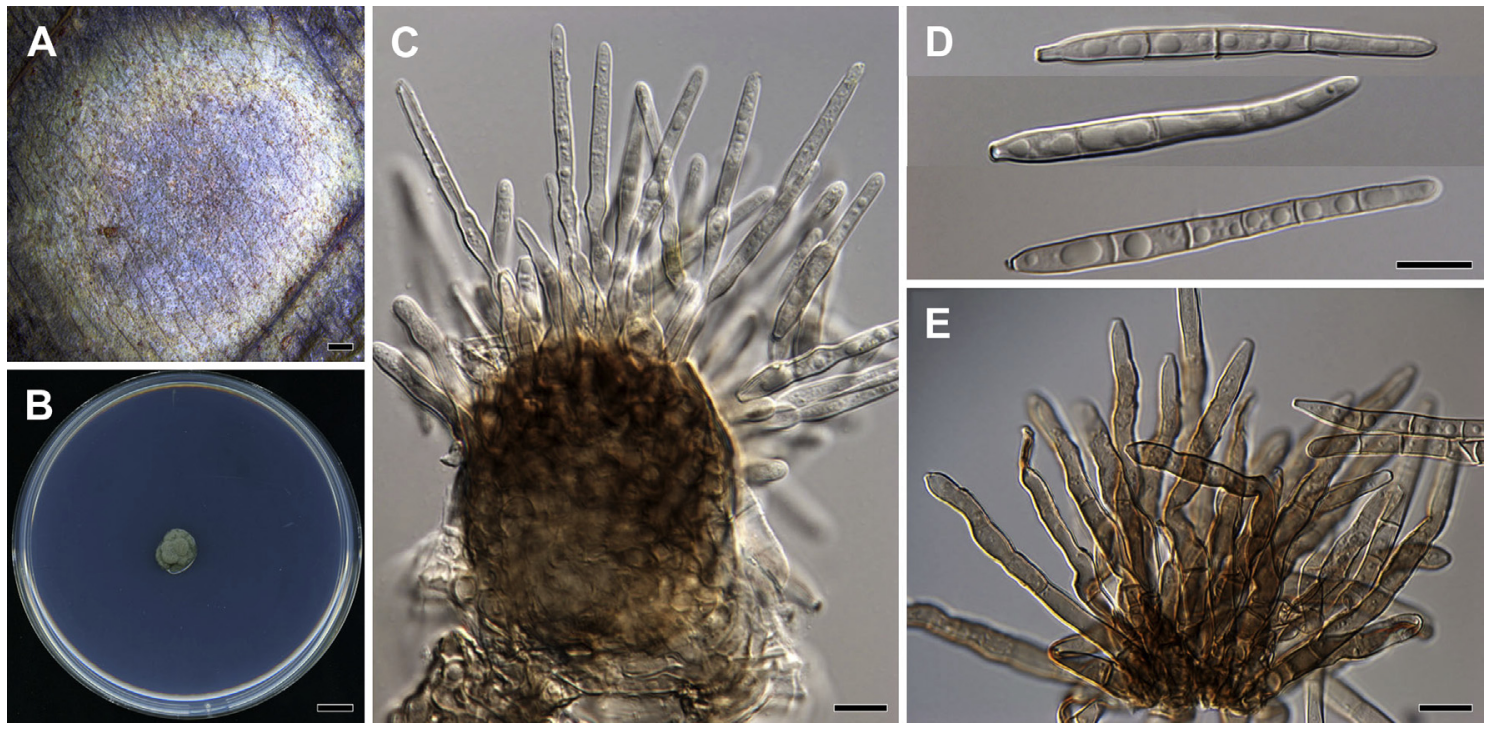

Fig 4 - Pseudocercospora proiphydis (from holotype BRIP 58545). (A). Leaf spot on Poirphys amboinensis; (B). Colony on PDA after 4 weeks; (C, E). Stromata and conidiophores; (D). Conidia. Bars: $(A)=1 \mathrm{~mm}$; $(B)=1 \mathrm{~cm}$; $(C-E)=10 \mu \mathrm{m}$.

with a diffuse pale yellowish green irregular halo that extends for up to $1 \mathrm{~cm}$. Caespituli hypophyllous, abundant on leaf spots, dense, dark, punctiform. Mycelium internal. Stromata erumpent from stomata, dark brown, up to 60 diam. Conidiophores in dense fascicles, arising from stromata, erect, subcylindrical to geniculate-sinuous, slightly tapered towards the apex, 10-30 × 2-3 $\mu \mathrm{m}$, unbranched, 0-3-septate, subhyaline to pale brown, smooth, thin-walled; conidiogenous cells integrated, terminal, subcylindrical, $10-25 \mu \mathrm{m}$, polyblastic, proliferating sympodially, condiogenous loci inconspicuous. Conidia formed singly, cylindrical to narrowly obclavate, straight curved to flexuous, truncate at the base and rounded at the apex, 35-75 × 3-6.5 $\mu \mathrm{m}, 1-6$-septate, subhyaline to pale brown, smooth, thin-walled; hila unthickened and not darkened, 1-2 $\mu \mathrm{m}$ wide.

Culture characteristics - (in the dark, $23^{\circ} \mathrm{C}$, after $4 \mathrm{wk}$ ): Colonies on PDA up to $2.5 \mathrm{~cm}$ diam., flat with scarce aerial mycelium, grey olivaceous (becoming olivaceous with age).

Typus. Australia, Queensland, Mt Conway, $20^{\circ} 16^{\prime} 44^{\prime \prime}$ S, $148^{\circ}$ $47^{\prime} 42^{\prime \prime} \mathrm{W}$, on leaves of Jagera pseudorhus var. pseudorhus (Sapindaceae), 3 Apr. 2013, R.G. \& M.D.E. Shivas (holotype BRIP 58549;
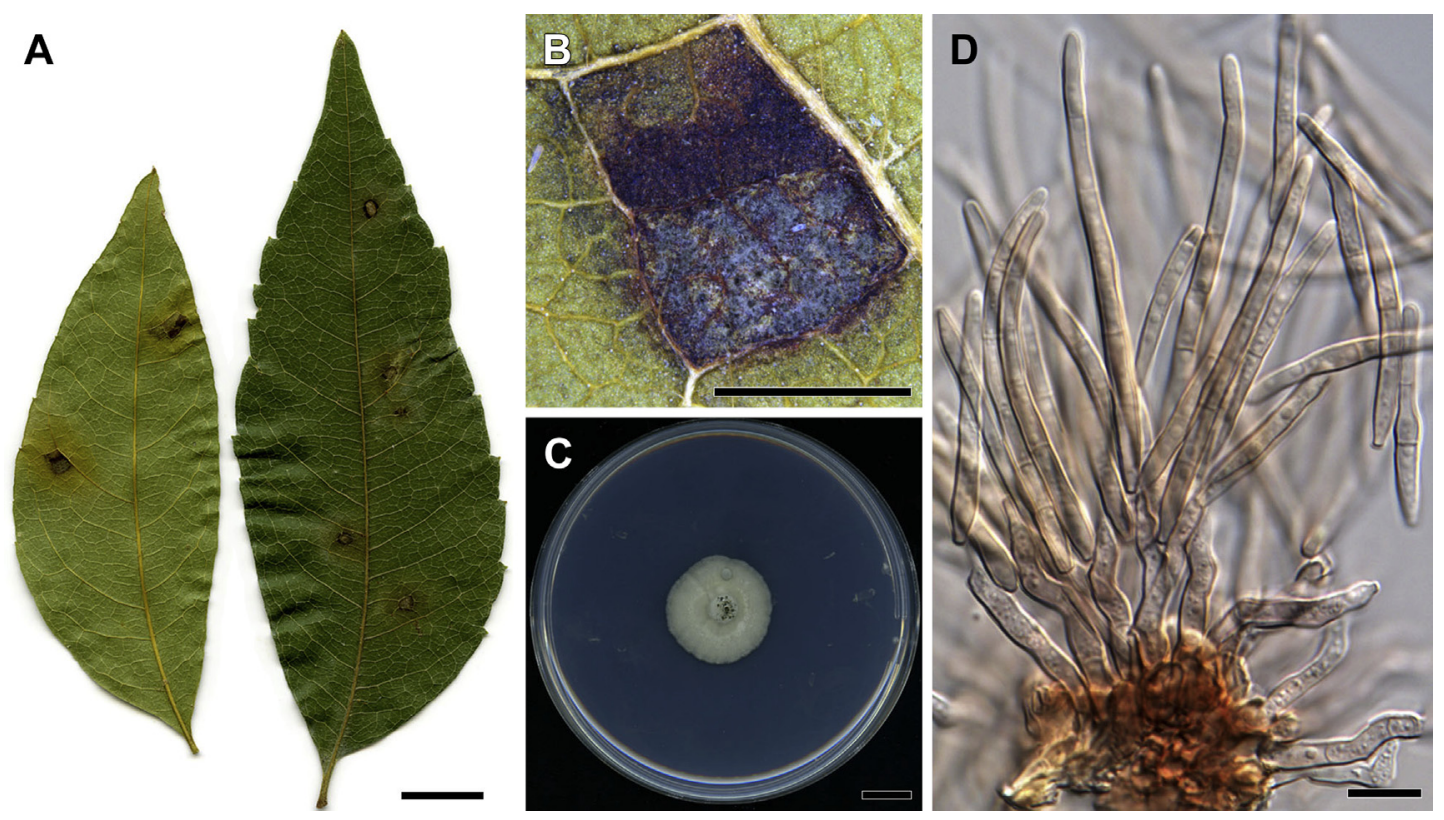

Fig 5 - Pseudocercospora jagerae (from holotype BRIP 58549). (A). Leaf spot on Jagera pseudorhus var. pseudorhus (abaxial leaf surface at left, adaxial leaf surface at right); (B). Leaf spot; (C). Colony on PDA after 4 weeks; (E). Conidiophores and conidia. Bars: $(A, C)=1 \mathrm{~cm} ;(B)=1 \mathrm{~mm}$; (D) $=10 \mu \mathrm{m}$. 
includes ex-type culture), ITS sequence GenBank KM055431, LSU sequence GenBank KM055435, EF-1 $\alpha$ sequence GenBank KM055438.

Notes - The host of $P$. jagerae is an endemic rainforest tree species that occurs in eastern Australia and the island of New Guinea. Only one species of Pseudocercospora, P. dodonaeae, has been reported from Australia on a host in the Sapindaceae (Beilharz \& Pascoe 2004). Chupp (1954) listed nine species of Cercospora (including two species as homonyms under C. alophyli), on hosts in the Sapindaceae. Six of these species, P. alophyli, P. allophylina, P cupaniae, P mitteriana, $P$. sapindi-emarginati, and $P$. thouiniae, were subsequently transferred to Pseudocercospora (Crous \& Braun 2003). None of these species occurs on Jagera, and none have been reported from Australia or New Guinea. Pseudocercospora fuligena (GU214675), P. chengtuensis (GU214672) and $P$. atromarginalis (GU214671) had the highest identities (99\%, $522 / 523$ identical base pairs) to $P$. jagerae in a BLAST search of the ITS region of rDNA. These three taxa, which differed by one base-pair in the ITS region occur on hosts in the Solanaceae.

\section{Discussion}

The newly described species of Pseudocercospora from Australian native plants were recovered in a monophyletic group considered Pseudocercospora s. str. by Crous et al. (2013). This clade, typified by Pseudocercospora vitis, is morphologically characterised by pale to dark brown conidiophores, with an inconspicuous conidial scar, and conidia that are usually scolecosporous with an unthickened and not darkened hilum. Crous et al. (2013) determined species of Pseudocercospora were mostly specific to a single host species and rarely pathogenic on several hosts. The Australian species of Pseudocercospora appear also to be host specific, and are differentiated by morphology and the ITS region of rDNA. The LSU region of rDNA was identical for the Australian species, Pseudocercospora airliensis, Pseudocercospora proiphydis, Pseudocercospora jagerae, Pseudocercospora avicenniae and Pseudocercospora casuarinae, which were recovered in a polytomy. One interpretation of the apparent close relationship between Australian species of Pseudocercospora, on diverse and unrelated native plant species, is that these fungi diverged as opportunistic pathogens from a recent common ancestor. Groenewald et al. (2013) discussed this possibility as an explanation for the rapid radiation of Cercospora, which was enabled by the production of cercosporin.

Future taxonomic studies on Pseudocercospora and other cercosporoid fungi in Australia and elsewhere should be based on morphology, sequence data and host association (Groenewald at al. 2013). Cultures of these fungi are essential for molecular based studies, yet unfortunately these are rarely established and preserved in collections. The Australian flora boasts over 30000 species of vascular plants (Orchard 1999) of which about $89 \%$ are native or endemic (Hnatiuk 1990). It is possible that the number of undiscovered and unidentified species of Pseudocercospora and other cercosporoid fungi in Australia will be substantial.

\section{R E F E R E N C E S}

Braun U, Castañeda RF, 1991. Cercospora and allied genera of Cuba (II). Cryptogamic Botany 2: 289-297.

Braun U, Crous PW, 2008. Cercosporoid hyphomycetes on hosts of the Annonaceae: Cercospora annonaceae and Isariopsis annonarum revisited. Mycotaxon 105: 207-224.

Beilharz V, Pascoe IG, 2004. New Australian disease record: Pseudocercospora dodonaea on Dodonaea spp. Australasian Plant Pathology 33: 429-431.

Carbone I, Kohn LM, 1999. A method for designing primer sets for speciation studies in filamentous ascomycetes. Mycologia 91: 553-556.

Chupp C, 1954. A Monograph of the Fungus Genus Cercospora Ithaca, New York.

Crous PW, Braun U, 2003. Mycosphaerella and its anamorphs. 1. Names published in Cercospora and Passalora. CBS Biodiversity Series 1: 1-571.

Crous PW, Aptroot A, Kang J-C, Braun U, Wingfield MJ, 2000. The genus Mycosphaerella and its anamorphs. Studies in Mycology 45: 107-121.

Crous PW, Braun U, Hunter GC, Wingfield MJ, Verkley GJM, Shin H-D, Nakashima C, Groenewald JZ, 2013. Phylogenetic lineages in Pseudocercospora. Studies in Mycology 75: 37-114.

Crous PW, Groenewald JZ, Shivas RG, 2010a. Pseudocercospora nephrolepidicola. Fungal Planet 59. Persoonia 25: 138-139.

Crous PW, Groenewald JZ, Shivas RG, 2010b. Pseudocercospora casuarinae. Fungal Planet 66. Persoonia 25: 152-153.

Crous PW, Groenewald JZ, Shivas RG, Edwards J, Seifert KA, Alfenas AC, Alfenas RF, Burgess TI, Carnegie AJ, Hardy GE StJ, Hiscock N, Hüberli D, Jung T, Louis-Seize G, Okada G, Pereira OL, Stukely MJC, Wang W, White GP, Young AJ, McTaggart AR, Pascoe IG, Porter IJ, Quaedvlieg W, 2011. Fungal planet description sheets: 69-91. Persoonia 26: 108-156.

Deighton FC, 1976. Studies on Cercospora and allied genera. 6. Pseudocercospora Speg., Pantospora Cif. and Cercoseptoria Petr. Mycological Papers 140: 1-168.

Deighton FC, 1979. Studies on Cercospora and allied genera. 7. New species and dispositions. Mycological Papers 144: 1-56.

Fresenius G, 1863. Beiträge zur Mykologie 3. Heinrich Ludwig Brömmer Verlag, Frankfurt.

Gardes M, Bruns TD, 1993. ITS primers with enhanced specificity for basidiomycetes - application to the identification of mycorrhizae and rusts. Molecular Ecology 2: 113-118.

Groenewald JZ, Nakashima C, Nishikawa J, Shin H-D, Park J-H, Jama AN, Groenewald M, Braun U, Crous PW, 2013. Species concepts in Cercospora: spotting the weeds among the roses. Studies in Mycology 75: 115-170.

Hnatiuk RJ, 1990. Census of Australian Vascular Plants Australian Flora and Fauna Series Number 11. AGPS Press, Canberra.

Katoh K, Asimenos G, Toh H, 2009. Multiple alignment of DNA sequences with MAFFT. Methods in Molecular Biology 537: 39-64.

McTaggart AR, Shivas RG, Ray JD, 2010. Pseudocercospora adansoniae. Fungal Planet 48. Persoonia 24: 134-135.

Nylander JA, Wilgenbusch JC, Warren DL, Swofford DL, 2008. AWTY (are we there yet?): a system for graphical exploration of MCMC convergence in Bayesian phylogenetics. Bioinformatics 24: 581-583.

O’Donnell K, Kistler HC, Cigelnik E, Ploetz RC, 1998. Multiple evolutionary origins of the fungus causing Panama disease of banana: concordant evidence from nuclear and mitochondrial gene genealogies. Proceedings of the National Academy of Sciences of the United States of America 95: 2044-2049.

Orchard AE, 1999. Introduction. In: . . In: Orchard AE, Thompson HS (eds), , Flora of Australia, 2nd ed., vol. 1, 
Australian Biological Resources Study/CSIRO Publishing, Melbourne, pp. 1-9.

Rayner RW, 1970. A Mycological Colour Chart. Commonwealth Mycological Institute, Kew, Surrey.

Ronquist F, Huelsenbeck JP, 2003. MrBayes 3: Bayesian phylogenetic inference under mixed models. Bioinformatics 19: 1572-1574.

Shivas RG, Young AJ, Crous PW, 2009a. Pseudocercospora avicenniae. Fungal Planet 40. Persoonia 23: 192-193.

Shivas RG, Young AJ, Grice KRE, 2009b. Pseudocercospora mangifericola. Fungal Planet 42. Persoonia 23: 196-197.

Shivas RG, Young AJ, McNeil BD, 2010. Pseudocercospora microsori. Fungal Planet 68. Persoonia 25: 156-157.

Spegazzini C, 1910. Mycetes Argentinenses (Series V). Anales del Museo Nacional de Historia Natural de Buenos Aires 20: 329-467.
Stamatakis A, 2006. RAxML-VI-HPC: Maximum likelihood-based phylogenetic analyses with thousands of taxa and mixed models. Bioinformatics 22: 2688-2690.

Vilgalys R, Hester M, 1990. Rapid genetic identification and mapping of enzymatically amplified ribosomal DNA from several Cryptococcus species. Journal of Bacteriology 172: 4238-4246.

White TJ, Bruns TD, Lee S, Taylor JW, 1990. Amplification and direct sequencing of fungal ribosomal RNA genes for phylogenetics. In: Innis MA, Gelfand DH, Sninsky JJ, White TJ (eds), PCR Protocols: a guide to methods and applications. Academic Press, San Diego, pp. 315-322.

Yen JM, Kar AK, Das BK, 1982. Studies on Hyphomycetes from West Bengal, India, I. Cercospora and allied genera of West Bengal, 1. Mycotaxon 16: 35-57. 